\title{
The History of Irish and Canadian Englishes: A Comparative Historical Overview
}

Dr. Yasir Sulaiman Almuways

Lecturer, College of Languages and Translation, Al-Imam Muhammad Ibn Saud Islamic University, Saudi Arabia; Researcher,

Mary Immaculate College, University of Limerick, Ireland.

Corresponding Author: Dr. Yasir Sulaiman Almuways, E-mail: ysalmuways@imamu.edu.sa

\section{ARTICLE INFORMATION}

Received: December 27, 2020

Accepted: February 09, 2021

Volume: 3

Issue: 2

DOI: 10.32996/ijels.2021.3.2.8

\section{KEYWORDS}

Irish English, Canadian English, English History, Lexicon, English

Varieties, Vocabulary

\section{ABSTRACT}

This article aims to compare and provide the historical linguistic background of Irish and Canadian Englishes in terms of their language history and lexicon. This research adopted the comparative historical research method which looks into the language history of one variety in comparison to another variety within the same language. Thus, this article discusses the history of Canadian English in comparison to the history of Irish English as well as the lexicon and vocabulary of Canadian English comparatively to the lexicon and vocabulary of Irish English which results in how the historical background in terms of culture and language and the geographical location of these two varieties have shaped, over time, what we now call Canadian English and Irish English which contain some differences and similarities to one another. This article results in the stages and the factors by which the lexicon of Irish English and Canadian English have been shaped and impacted.

\section{Introduction}

Canadian English and Irish English are considered to be amongst the major varieties of English today. Canadian English is spoken by approximately twenty million people whereas Irish English is spoken by approximately five million people (Barber 2004; Dolan 2013). Each one of these two English varieties has been shaped linguistically by many factors that have had a huge impact on them. Irish English has been largely influenced by England (British English) mainly due to its geographical location, political situation, and historical events. Another main influence on Irish English is the Irish language (Gaelic) (see Hickey 2011). Canada, on the other hand, has been affected linguistically by the settlers who had migrated to Canada. One of those settler groups were the Irish people who came and migrated to Canada after the War of 1812 (Boberg 2004). Since then, this connection between Ireland and Canada has been documented historically in terms of culture and language. However, even though there is an established connection between the two varieties of English, there has not been a lot of research done on these two varieties of English in comparison to each other in general and especially in relation to their lexicon. In other words, there have not been many works, or studies, that have compared or provided the historical background of Irish and Canadian Englishes in comparison to each other. Thus, this article seeks to address this research gap specifically in terms of the Irish and Canadian Lexicon.

\section{Literature Review}

\subsection{The History of English}

English is the most recognized language around the world; but, how did it reach that status? Ironically, although the spread of the English language can be attributed to the colonization of other countries by Britain, the origins of English lie in the conquest and invasion of Britain itself by other neighbouring groups (Baugh \& Cable 2002; Algeo 2010; Ringe \& Taylor 2014).

The indigenous language of Britain was Brittonic Celtic (Hogg 1992; Flippula, Klemola \& Pitkänen 2002). With the arrival and invasion of Germanic settlers between the fifth and seventh centuries, Brittonic Celtic was eventually wiped out and replaced with Anglo-Saxon, more commonly known as Old English (Ringe \& Taylor 2014). Old English is a West Germanic language originating from Anglo-Frisian dialects (McCrum 1987; Salmon 2009). Because of this, and due to many other reasons as well, it is not surprising that Old English was comprised of many dialects of its own. At the time, the region which is now known as

K C AL-KINDI CENTER $\mathbf{R}$ FOR RESEARCH AND $\mathbf{R}$ DEVELOPMENT Your gateway to world-class research

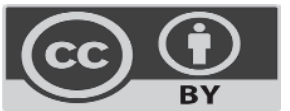

Published by Al-Kindi Center for Research and Development. Copyright (c) the author(s). This open access article is distributed under a Creative Commons Attribution (CC-BY) 4.0 license 
Britain was divided into many different Anglo-Saxon kingdoms, each with its own dialect and outside influence. For example, Old English is heavily influenced by Old Norse because of Scandinavian rule in the eastern and northern parts of England (McCrum 1987; Mastin 2011a). However, the dialects can be narrowed down to four main dialects: Mercian, Northumbrian, Kentish, and West Saxon; the latter of which eventually became the dominant dialect. Old English also made heavy usage of loanwords from Latin due to two main reasons. The first of which was the fact that many of the Germanic settlers who came to Britain had previously served in the Roman military and so their language already contained a lot of Latin loanwords. Naturally these loanwords made their way into the new settlement and became a part of Old English. Secondly, around the year 600, Christianity was quickly gaining popularity in the region and becoming more widespread and because of it there were approximately another 400 loanwords from Latin that made their way into Old English.

The influence of the Germanic invaders and settlers ended with the Norman Conquest in 1066, marking the advent of Middle English (Hogg 1992; Mastin 2011b). The surviving influence of the North Germanic languages into this period was that of the Scandinavians in the eighth and ninth centuries whereby the effects of simplified grammar and lexical borrowings were seen (Champneys 1893). The conquering Normans, however, spoke a form of French known as Old Norman which developed into Anglo-Norman in Britain (Mastin 2011b). The main effect of Old Norman onto Middle English was the addition of over 10, 000 loanwords, especially those related to the church, the court system, and the government (Mastin 2011b). One of the lasting remnants of Middle English is its orthography (Fulk 2012). The orthography developed during this period is still mostly used today; but, changes in pronunciation, and the adoption of various foreign spellings means that the spelling of Modern English words is very unusual. Most abstract nouns ending with -age, -ance/-ence, -ant/-ent, -ment, -ity, and -tion, or beginning with the prefixes con-, de-, ex-, trans-, and pre- come from this Middle English era (Mastin 2011b).

The effects of the Norman conquest lasted until the $15^{\text {th }}$ century, which is when historians mark the beginnings of Early Modern English as was spoken by Shakespeare's contemporaries (Barber 1997; Nevalainen 2006). The main changes to occur to the language at this point were more loan words taken from Latin and Ancient Greek (due to the Renaissance) and borrowings from other European languages such as French, German, and Dutch. This period is also where the ongoing Great Vowel Shift found its origins; so, many pronunciation changes occurred during this era between the fifteenth to seventeenth centuries (Stockwell 2002; Mastin 2011c). The Great Vowel Shift was largely concerned with the long vowel sounds and had to do with their movement upwards and forwards in the mouth (Mastin 2011c). The other notable factor that had a great impact on the English language during this time period was the invention of the printing press in 1476 which enabled a standardization of English to occur across the nation (Howard-Hill 2006; Mastin 2011c). This leads us to the emergence of proper Modern English in the 17th century.

\subsection{The Spread of English Around the World}

In today's world of globalization English has, arguably, emerged as the global lingua franca. English is now the dominant language of Britain, Ireland, the United States, Canada, Australia, and New Zealand. Furthermore, approximately 75 territories use English as a first language (L1) or as an official, institutionalized second language (L2) (Jenkins 2015, p. 2). English is also widely spoken in India, and other parts of Asia, as well as several parts of Africa. The number of countries using English as a main language of communication is on the rise. This global popularity and usage of English can be explained in a historical and modern sense.

One of the historical factors contributing to the spread of English around the world was through the likes of adventurers. Much of Southeast Asia, East Asia, and the South Pacific came under English influence due to seafaring expeditions undertaken by British explorers in the late eighteenth century (Jenkins 2015, p 9). Historically speaking however, the main avenue for the domination of English on a global scale was through colonization.

Britain became a great colonial power from the sixteenth century onwards. There were two main types of colonization: 1) settler colonies and 2) exploitation (or trade) colonies (Kirkpatrick 2012, p 15). Settler colonies were those in which a large number of British citizens migrated and settled down. Because these countries had a larger number of native English speakers, the strength and spread of English was much more rapid and "pure" to the original British English. Jenkins expands on the latter type of colonization and explains that, depending on the location, the spread and type of English to become established was likely to differ. In West Africa, for example, which was used for the slave trade, English manifested itself with the native populations by morphing into pidgins and creoles due to the lack of proper interaction and integration between the English and the natives (Jenkins 2015, p 8). East Africa, on the other hand, became home to many native English speakers and thus "proper" colonies were formed here. As a result, English was spoken and used in the governmental, educational, and legal sectors in those countries (Jenkins 2015, p 8). South Asia, which was also a colony of the British Empire where many British citizens settled, began having a larger English influence in the latter part of the eighteenth century with the implementation of the Macaulay Minute of 1845 which led to the introduction of English into the school system (Jenkins 2015, p 9). 
This leads us to one of the modern factors contributing to the continued spread of English around the world which is the Education system. Many countries choose to educate their population in the primary grades in the English language. This is despite the United Nations Educational, Scientific, and Cultural Organization's (UNESCO) insistence that "the child should be taught through the mother tongue." (Kirkpatrick 2012, p. 24). However, the countries implementing this policy do not pay attention because they believe that English is "the language of science, technology, and modernization" and that the earlier it is acquired the more fluent a child has the potential to become in it (Kirkpatrick 2012, p 24). And while it may pose potential difficulties for students. it is true that after the First World War, English has become the global language of Science (Ferguson 2006, p 112). Not only has it become the global language of science, it has also become the main language of commerce and trade. Many multinational companies make use of English as a common language in which to communicate business dealings. This is one of the main reasons for the spread of English in East Asia today. Another modern factor aiding the spread of English today is the entertainment industry. English has permeated and popularized itself through music, satellite broadcasting, home computers, and video games; as well as illegal activities such as drugs and pornography (Jenkins 2015, p 41). Lastly, the growing economic, military, and political power of the United States in the late twentieth century has been a very strong influencing factor towards the spread of English (Ferguson 2006, p. 110).

\subsection{How Did We Get to Have Different Varieties of English?}

One of the only monolithic features of English across the globe is its ability to morph and change once it reaches new communities. So, despite the fact that English has emerged as the lingua franca of our newly globalized world, it is also a reality that there is no such thing as one singular English (Seidlhofer, 2001; Conrad \& Mauranen 2003). Thus, linguists use the term Englishes to refer to the different types, or varieties, of English that are now spoken worldwide. There are several theories to explain how these various Englishes came to be. One of the more popular and well-known theories is Kachru's three circle model which comes primarily from a colonization viewpoint (Kachru 1985). The three circles are comprised of the inner circle, the outer circle, and the expanding circle (Galloway and Rose 2015, p 18). The Inner Circle consists of Britain, America, Canada, Australia, New Zealand, and South Africa. These are considered to be the "traditional cultural and linguistic bases of English" (Kirkpatrick 2012, p 16). The Outer Circle are those that made up the British colonies designed for trade and exploitation and their English can be categorized as an "institutionalised non-native variet[y] of English as a Second Language (ESL)" (Kirkpatrick 2012, p 16). Lastly, the Expanding Circle includes all the countries and areas where English is currently learned as a foreign language (Kirkpatrick 2012, p. 16).

However, because each of the countries and categories mentioned above are no longer a singular, monolithic group due to constant people migration, the breakdown of Englishes must be taken down further. The increased mobility of people around the world "produces a continued diversity in the way that the language itself alters as it adapts to the emergent cultures of the diverse communities using it" (Seargeant 2012, p. 184). Thus, English has become multiplex, meaning that it does not have only one centre (Britain) influencing its shape and usage, but has multiple centres in multiple communities (Seargeant 2012, p. 186). The social implications of this are equally vast. This is because, in relation to the three-circle model, different types of English have different values and social connotations (Seargeant 2012, p. 186). Where and how a type of English is spoken matters. Whereas speaking English in a country that belongs in the Inner Circle may be seen as commonplace, fluency in English can be a mark of higher social status, or an increased chance for success in a country belonging to the Expanding Circle. Furthermore, the type of English spoken in Outer Circle countries does not seem out of place within those countries or areas themselves; however, if that same type of English is spoken while being in an Inner Circle country, it may lead to racism or classism (Seargeant 2012, $p$ 186).

\section{Methodology}

This study has used the comparative research method based on the historical perspective of the language history of both Irish and Canadian Englishes, as a technique for studying and exploring the development of two varieties of the same language. This comparative method is well known in Linguistics in which the internal development of a single language can be conducted and inferred through the analysis of any particular features or linguistic systems across different varieties within one language. This comparative research method can help researchers to confirm or refute any hypothesized relationships between languages or varieties of the same language.

\section{Introduction to Canadian English and Irish English 4.1 The History of Canadian English}

The term "Canadian English" was created and provided by Geikie, a Scottish-born Canadian, in his speech to the Canadian Institute in 1857 (Dollinger 2013). Thus, he was the first person in recorded history to use this term. He used the term, "Canadian English," to promote the notion of ethnocentrism in order to distinguish between the "corrupt" dialect of English spoken in Canada and the "proper" English spoken by British immigrants (Dollinger 2013). Canadian English has been shaped by many 
factors and one of those important factors is the regional factor and this can be seen by looking into the different English dialects within Canada (Trudgill, 1974; Chambers and Hardwick 1986; Boberg 2005; Hagiwara 2006; Roeder \& Jarmasz 2010; Harbeck 2014). For example, the North Central region of the United States of America (U.S.) has dialect similarities with Ontario, whereas British Columbia and the Northwestern area of the United States share a similar dialect called Northwest English, which is a variety of North American English (Avis 1973; Harbeck 2014).

More importantly, however, Canadian English has been shaped by four waves of immigration and settlement. The first wave of immigrants to have an impact on Canadian English were the Loyalists. The Loyalists were American Colonialists who stayed loyal to the British empire during the American Revolutionary War (Bloomfield, 1948; Boberg 2004). Loyalists came to Canada in the early 1760s from a region in the United States located between New England and the South Atlantic states (Bloomfield 1948; Temperley 1979; Boberg 2004). Because of this, some scholars believe that Canadian English is derived from Northern American English (Bloomfield 1948; Boberg 2004). The second group of settlers who played a big role in shaping Canadian English are those who came to Canada from Britain and Ireland after the war of 1812 (Bloomfield 1948; Boberg 2004). This movement was encouraged by the governors of Canada in order to wipe out anti-English views amongst its citizens. The third wave was from the immigrants who came from all over the world between 1910 and 1960 (Bloomfield 1948; Boberg 2004). This new settlement was the starting point for Canada to be a multi-cultural state. The fourth wave to have an impact on creating a Canadian English was the French settlers who settled down in the east of Canada by the mid-1 $17^{\text {th }}$ century. The French settlement is considered to be the oldest European settlement in Canada (Bloomfield 1948; Boberg 2004).

The factors mentioned above identify how English arrived and spread throughout Canada. But, an equally important factor to look into is: how was English able to take over the many languages used by the First Nations peoples of Canada who were the original inhabitants of the country long before European settlers arrived. The loss of Aboriginal languages was made possible through the use of residential schools. Residential schools in Canada were sponsored and controlled by the Canadian government and Christian churches in order to assimilate indigenous children into the European-Canadian culture. The first residential schools were established after 1880 (Miller 2012). The approach that was taken to get aboriginal children to adapt themselves to the new lifestyle was to forcibly remove them from their families and culture and forbid them from using their mother tongue language among each other. Failure to abide by these rules would result in punishment and abuse. The last residential school was closed in 1996, and although the school system proved to be very effective in wiping out the First Nations languages and increasing the usage of Canadian English amongst the indigenous population, it did so by isolating, denigrating, abusing, and even killing the First Nations population (Miller 2012).

As it stands today, Canadian English is a variety of English spoken by approximately $60 \%$ of the Canadian population and is considered to be the mother tongue of $60 \%$ of Canadians. This is a very low percentage, especially if English is considered to be the first language in Canada. This is due to the fact that $20 \%$ of Canadians speak French and the remaining $20 \%$ speak other languages such as Chinese (8\%), Punjabi (5\%), Italian (4\%), and Portuguese (2\%) (Boberg 2004). Because Canadian English contains a combination of British and American English vocabulary and spelling, as well as many unique Canadianisms, it has a very unique vocabulary and spelling of its own.

\subsubsection{The Canadian English Lexicon and Vocabulary}

The Canadian lexicon can be viewed and classified into four main categories. The first category contains and highlights the notion of archaism, which are old expressions that are no longer used elsewhere except in Canada. For example, the expression I guess, means 'I suppose' in Canadian English. Also, the term trash which means 'garbage' in Canadian English is another example (Hamilton 1997, Section 2.1.1). The second category covers existing words which have had their meanings extended in Canada. For example, the word band simply means: a group of people; however, its meaning has been modified to include a group of Indians in a particular region recognized by the political state as a group (Hamilton 1997, Section 2.1.2). The term acclamation which means "a vote to accept or approve someone or something that is done by cheers, shouts, or applause" [according to Merriam Webster] is another example. In Canada, an additional semantic element must be included in the meaning which is "assent without any opposition," and this is according to the Canadian Oxford Dictionary which defines it as "the act or an instance of electing without opposition" (Hamilton 1997, Section 2.1.2). The third category covers the new words that have been created from existing languages or words. For example, the process of compounding which joins two or more existing words to generate a new term. And this can be seen in the expression of prairie crocus and beverage room. Another way that new words are created from existing words is through the process of blending, whereby two or more words are blended together. For example, the term splake comes from a Canadian biologist who crossed a speckled trout and a laketrout, and gave the resulting specimen the name, "splake" (Hamilton 1997, Section 2.1.3).

The fourth category focuses on the words that have been borrowed from other languages. In this category, the terminology that 
comes from the Aboriginal people of Canada has had the most powerful impact on lexical Canadianisms. This is because Europeans heavily relied on the Amerindians when they first moved to Canada in order to adapt themselves to the new environment and surroundings. Some of these words are: muskeg, Saskatoon, toboggan, and wapiti. Also, French has had an apparent impact on lexical Canadianisms, especially after English and French speakers became neighbours. Some of these words are: portage, prairie, rapids, and concession. The borrowing process has either kept the original forms or modified them in order to fit the linguistic system of the target language (Hamilton 1997).

\subsection{The History of Irish English}

The language shift in Ireland, from Irish to English, was a very gradual process with a number of noteworthy events in each century leading up to the present day pervasiveness of Hiberno English throughout the country (Bliss 1977; 1979; Kallen 1994). Even in Gaeltacht areas, where the main language spoken by the Irish is Gaelic, English is still a known language. According to Hickey, English came to Ireland a little over 800 years ago $(2007$, p.1). Although the first foreign arrivals in Ireland are recorded to have spoken Anglo-Norman, Welsh, and Flemish, the latter two have left no lasting influence on Irish English (Hickey 2007, p. 30). However, the source of the largest influence on the language shift in Ireland has been England (Kallen 1994).

Ireland and England have had close ties since the late Middle Ages due to trade and England's invasion of Ireland in 1169 (Hickey 2007, p 30). The first area to undergo an English influence was Dublin as the city was occupied by English invaders after their arrival in the 1170s (Hickey 2007, p 30). The emergence and prevalence of English in Ireland is very closely tied to the political sentiment of England over the years (Bliss 1979; Kallen 1994). Because much of England's rise to power was its claim to a divinely appointed King, this belief was used to increase the level of English spoken in the increasingly religious Ireland (Hickey 2007, p 34). The Irish were mostly seen as "heathens" by the English and this belief led to the necessary "civilization" and religious indoctrination process that would be conducted in English which was taken on during the Reformation during the Tudor period (1485-1603) (Hickey 2007, pp 34-35).

There was a relatively short period of time in the late fourteenth and fifteenth centuries where Gaelic became popular again due to England's lack of political interest in its subjects living there. This period is significant because it occurred during a transition period for English in England. Whereas in Ireland, Gaelic was flourishing and becoming widespread; in England, Middle English was becoming Modern English. So, when this period was followed by an even larger scale settlement of the British people in the following century, the English that the British heard from the Irish was a much older form and had been heavily influenced by Gaelic, or Irish (Hickey 2007, p. 32; Mcglynn 2004). In the mid 1500s England fully took over all of Ireland and divided the land into plantations which it gave to the Old English (English settlers from previous invasions) to take charge of as the Irish were not allowed to own these properties (Hickey 2007, p 36). At this point, two factors had a big influence on the language shift of native Irish people. The first were the Penal Laws (Bryne 2004, 230f; Hickey 2007, p. 37) which imposed punishment on the use and practice of the Irish language, and the second were the social advantages to be gained by knowing English (Hickey 2007, p 38). The eighteenth century also had two major social areas of interest that may have affected modern Irish English today (Bliss 1979). The first of which was the popularization of elocution in the British Isles which is "the cultivation of a standard accent by non-standard speakers for the purpose of public speaking." (Hickey 2007, p 44). Evidence of the permeation of this notion can be seen in eighteenth century Dublin English (Hickey 2007, p 44). The second were Catholic "hedge schools" which cropped up throughout Ireland. Hedge schools were informal, unofficial schools, usually held outside, where students were mainly educated for priesthood (Hickey 2007). And English as a language would have definitely been one of the classes offered in these hedge schools. Naturally, the teachers were not native English speakers so they would have been passing on the accent of a second language learner. This somehow contributed in shaping the phonological system of Irish English and creating unique stress patterns in Irish English.

Nineteenth century Ireland saw another two social events that further progressed the language shift in Ireland (Bliss 1977). The first was the Catholic Emancipation Act of 1829 which allowed Catholics to legally open their own schools and their leader, Daniel O'Connell, encouraged them to take on English as their official language (Hickey 2007, p. 46). The second major event was the Great Famine in Ireland which led to the death of large numbers of Native Irish speakers. Along with this, there was also an exodus of Irish people to America, which further reinforced the need to know English in order to not only succeed, but to survive. Thus, the language shift in Ireland was mainly a non-prescriptive, uncontrolled language learning process and was mainly undertaken by Irish adults first and then passed on to their children (Bliss 1972; Hickey 2007, p. 125).

\subsubsection{The Irish English Lexicon and Vocabulary}

In regard to the Irish lexicon, it must first be noted that there is a difference between the lexicon of northern and southern Irish English (Bliss 1984; Hickey 2007, p. 362; Amador-Moreno 2010). It can also be argued that there is currently a growing generational divide in Irish English as well (Flippula 1991). This is because Irish derived vocabulary is more commonly used amongst the older generations (Hickey 2007, p. 365). Presently, Irish words are used in official capacities, such as in the 
government to refer to ministries or official positions; however, even though Irish people will commonly use these terms due to their prevalence, very few will actually be able to discern what the word truly means or where it originates from (Irish) (Hickey 2007, p 365). Another way in which Irish words are used in Irish English is a phenomenon known as Cupla focal or a 'couple of words' whereby Irish English speakers pepper their speech with a few words from Irish (Kallen 2006). This doesn't reflect a knowledge or fluency in the Irish language; rather, it is just a parroting of what has been learned in school (Hickey 2007, p.364). But, still, there are actual Irish loanwords in Irish English and they are mostly related to Irish manners and life (Flippula 1991). Their usage can be very difficult to master and because they are often used in highly colloquial speech and can differ region to region, using a word incorrectly can give one away as a non-Irish, or non-local individual (Hickey 2007, p. 364).

As can be seen from the explanation above, not all words in Irish English come from Irish. Some are archaic in their origin or regional in their usage e.g. cog 'cheat' or chisler 'child' while others maintain archaic usage such as mad is used as 'keen on' in Irish English, rather than 'angry' or 'crazy' as in Standard English (Hickey 2007, p. 362). Some words have a foreign origin but enter Irish English through English. An example of this is hames (from Dutch) which originally means 'curved pieces forming horse collar' but is used in Irish English to mean 'complete failure, mess' (Hickey 2007, p. 362). Additionally, a feature that is unique to Irish English is the tendency to interchange complementary words in the Irish lexicon; teach and learn is an example of this phenomenon (Hickey 2007, p. 362).

And of course, Irish English shares many words with Standard English; however, many changes have occurred during the crossover which render these words and their usage as strictly Irish English (Amador-Moreno 2010). An example of this is how different pronunciations of English words can change the connotation of a word in Irish English. For example, pronouncing idiot as eejit gives an implied meaning of a 'bungling person' (Hickey 2007, p 362). It is not only the pronunciations but sometimes Irish English will take English words or phrases and give their own completely separate and unique meaning to them (Bliss 1984; Hickey 2007; Amador-Moreno 2010). For example, the English word leave would give the sense of 'accompany' or 'bring' in the Irish lexicon (Hickey 2007, p. 362). At times, words in the Irish English lexicon can be homographs with English words and so the Irish English and English words have very different meanings (Hickey 2007, p 363). Another way Irish English adapts Standard English words is through semantic extensions whereby an adjective such as grand can be used in a very casual manner to signify approval rather than sticking to the original meaning of something over the top and special (Hickey 2007, p. 363). The Irish will commonly say That's grand to simply mean "That's alright" or "That's okay". Another feature of Irish English is to use English adverbs as intensifiers: 'We were pure robbed by the builders' (Hickey 2007, p 363). Finally, a morphological change of adding -er creates new words in Irish English from Standard English words so a word like killer becomes "something that would stress you out" in Irish English, rather than "a murderer" (Hickey 2007, p. 363; Amador-Moreno 2010).

\section{Conclusion}

The article has compared and provided the historical linguistic background of Irish and Canadian Englishes in comparison to each other in terms of language history and lexicon. This research adopted the comparative historical research method in order to reveal the language history and the lexicon of both Irish English and Canadian English in comparison to one another.

This article demonstrates how the historical background in terms of culture and language and the geographical location of these two varieties have shaped, over time, what we now call Canadian English and Irish English which contain some differences and similarities to one another. This article results in the stages and the factors by which the lexicon of Irish English and Canadian English have been shaped and impacted. For further research it will be recommended for researchers to take the method of internal reconstruction where the feature-by-feature comparison, or the phonological, morphological and other linguistic systems are conducted historically.

Funding: This research received no external funding.

Conflicts of Interest: The author declares no conflict of interest.

\section{References}

[1] Algeo, J. (2010). The Origins and Development of the English Language. Boston, MA: Wadsworth. pp. 140-141.

[2] Amador-Moreno, C.P. (2010). An introduction to Irish English, London: Equinox

[3] Avis, Walter S. (1973). The English language in Canada. In Thomas A. Sebeok (ed.), Current Trends in Linguistics 10: Linguistics in North America, (pp 40-74). The Hague: Mouton.

[4] Barber, C.L. (1997). Early Modern English. Edinburgh University Press.

[5] Barber, K. (ed). (2004). Canadian Oxford Dictionary: Second Edition. Oxford University Press: Don Mills, Ontario.

[6] Baugh, Albert C. and Thomas Cable. (2002). A History of the English Language. $5^{\text {th }}$ Edition. Upper Saddle River, N.J.: Prentice Hall.

[7] Bliss, A.J. (1972). Languages in contact: Some problems of Hiberno-English. Proceedings of the Royal Irish Academy, 72, 63-82.

[8] Bliss, A.J. (1977). The emergence of modern English dialects in Ireland. In Ó'Muirithe, D., ed., The English language in Ireland, Dublin: The Mercier Press.

[9] Bliss, A.J. (1979). Spoken English in Ireland, 1600-1740. Dublin: Dolmen Press. 
[10] Bliss, A.J. (1984). English in the south of Ireland. In Trudgill, P., ed., Language in the British Isles, Cambridge: Cambridge University Press, 135151.

[11] Bloomfield, M. (1948). Canadian English and its relation to eighteenth century American speech. Journal of English and Germanic Philology 47: (pp 59-67).

[12] Boberg, C. (2004). English in Canada: phonology. In Kortmann, Bernd and Edgar W. Scheider (eds), A Handbook of varieties of English: a multimedia reference tool. (pp 351- 365). Berlin: De Gruyter.

[13] Boberg, C. (2005). The Canadian Shift in Montreal. Language Variation and Change 17. Pp. 133-154.

[14] Chambers, J.K. and Margaret Hardwick. (1986). Comparative sociolinguistics of a sound change in Canadian English. English World-Wide 7. Pp. 23-46.

[15] Champneys, A.C. (1893). History of English: A Sketch of the Origin and Development of the English Language. Books.google.com. Retrieved 2017-04-04.

[16] Conrad, S. and Anna Mauranen. (2003). The corpus of English as lingua franca in academic settings. TESOL Quarterly 37, 3. Pp. 513-527.

[17] Dolan, Terence P. (2013). A Dictionary of Hiberno-English: Third Edition. Terence Patrick Dolan (ed). Gill and MacMillon: Dublin.

[18] Dollinger, S. (2013). Canadian English- Oxford English Dictionary. Retrieved March 18, 2016, from http://public.oed.com/aspects-ofenglish/english-in-use/canadian-english/.

[19] Ferguson, G. (2006). Language planning and education. Edinburgh University Press.

[20] Filppula, M. (1991). The relevance of linguistic constraints on inter-language transfer: Evidence from Irish English. Teanga, 11, 9-19.

[21] Filppula, M. (1999) The grammar of Irish English: Language in Hibernian style. London: Routledge.

[22] Filppula, M., Juhani Klemola and Heli Pitkänen (eds). (2002). The Celtic Roots of English. Joensuu: University of Joensuu, Faculty of Humanities.

[23] Fulk, R.D.(2012). An Introduction to Middle English. Broadview Press.

[24] Galloway, N. \& Heath Rose. (2015). Introducing Global Englishes. London: Routledge.

[25] Hagiwara, R. (2006). Vowel production in Winnipeg. Canadian Journal of Linguistics 51. Pp 127-141.

[26] Hamilton, S. (1997). Types of Canadianisms. (Unpublished doctoral dissertation). University of Ottawa, Ottawa.

[27] Harbeck, J. (2014). Why it's difficult to tell a Canadian accent from a Californian one. The Week. The Week Publications, Inc.

[28] Hickey, R. 2007. Irish English: History and Present day forms. Cambridge: CUP.

[29] Hogg, R. M. (ed.). (1992). The Cambridge History of the English Language (Vol. 1): the Beginnings to 1066. Cambridge: Cambridge University Press.

[30] Howard-Hill, T.H. (2006). Early Modern Printers and the standardization of English spelling. The Modern Language Review Vol 101. No. 1. Modern Humanities Research Association. Pp 16-29.

[31] Jenkins, J. (2015). Global Englishes: A resource book for students. London: Routledge.

[32] Kachru, B. B. (1985). Standards, codification, and sociolinguistic realism: The English language in the outer circle. In R. Quirk and H. Widdowson, (eds) English in the World: Teaching and Learning the language and the literature. Cambridge: Cambridge University Press.

[33] Kallen, J.L. (1994). English in Ireland. In Burchfield, R.W., ed., English in Britain and Overseas: Origins and development: The Cambridge History of the English Language, Vol. V, Cambridge: Cambridge University Press.

[34] Kallen, J.L. (2006). Arrah, like, you know: The dynamics of discourse marking in ICE- Ireland. accepted for $16^{\text {th }}$ Sociolinguistics Symposium, Limerick, 6-8 July, available: http://hdl.handle.net/2262/50586 [accessed 31 July 2011].

[35] Kirkpatrick, A. (2012). Theoretical issues. In EE-Ling Low \& Azirah Hashim (eds), English in Southeast Asia: Features, policy and language in use, (pp. 13-31). Amsterdam: John Benjamins.

[36] Mastin, L. (2011a). Old English. History of English. Retrieved 02 May 2016 from, http://www.thehistoryofenglish.com/history_old.html.

[37] Mastin, L. (2011b). Middle English. History of English. Retrieved 02 May 2016 from, http://www.thehistoryofenglish.com/history_middle.html

[38] Mastin, L. (2011c). Early Modern English. History of English. Retrieved 02 May 2016 from, http://www.thehistoryofenglish.com/history_early_modern.html.

[39] McCrum, R. (1987). The Story of English. London: Faber and Faber. pp. 70-71

[40] McGlynn, A. (2004). Hiberno-English: The English language in Medieval Ireland. Retrieved 04 May 2016 from, http://homes.chass.utoronto.ca/ cpercy/courses/6361 mcglynn.htm.

[41] Miller, J.R. (2012). Residential Schools. Tabitha Marshall (ed) (2015). In The Canadian Encyclopedia online. Retrieved 18 March 2016, from, http://www.thecanadianencyclopedia.ca/en/article/residential-schools/.

[42] Nevalainen, T. (2006). An Introduction to Early Modern English. Edinburgh: Edinburgh University Press.

[43] Ringe, D. R. and Ann Taylor. (2014). The Development of Old English - A Linguistic History of English, vol. II. Oxford.

[44] Roeder, R. and Lidia-Gabriela Jarmasz. (2010). The Canadian shift in Toronto. Canadian Journal of Linguistics 55, 3. Pp. 387-404.

[45] Salmon, V. (2000). The Cambridge History of the English Language, Vol. III. Robert Lass (ed). Cambridge University Press. p. 39.

[46] Seargeant, P. (2012). English and linguistics globalisation. In Philip Seargeant \& Joan Swann (eds), English in the World: History, diversity and change, (pp 178-187). Abingdon: Routledge.

[47] Seidlhofer, B. (2011). Understanding English as a Lingua Franca. Oxford University Press.

[48] Stockwell, R. (2002). How much shifting actually occurred in the historical English vowel shift? (PDF). In Donka Minkova \& Robert Stockwell (eds), Studies in the History of the English Language: A Millennial Perspective. Mouton de Gruyter.

[49] Temperley, H. (1979). Frontierism, Capital, and the American Loyalists in Canada. Journal of American Studies, 13(1), 5-27.

[50] Trudgill, P. (1974). Linguistic change and diffusion: Description and explanation in socio-linguistic dialect geography. Language in Society 3. Pp 215-246. 